\title{
Large brown seaweeds of the British Isles: evidence of changes in abundance over four decades
}

Chris Yesson ${ }^{1,2 *}$, Laura E. Bush ${ }^{3}$, Andrew J. Davies ${ }^{3}$, Christine A. Maggs ${ }^{4}$ \& Juliet Brodie ${ }^{1}$

${ }^{1}$ Natural History Museum, Department of Life Sciences, Cromwell Road, London, SW7 5BD, United Kingdom.

${ }^{2}$ Institute of Zoology, Zoological Society of London, Regent's Park, London, NW1 4RY, United Kingdom.

${ }^{3}$ School of Ocean Sciences, Bangor University, Menai Bridge, Anglesey, LL59 5AB, United Kingdom.

${ }^{4}$ School of Biological Sciences, Queen's University Belfast, Medical Biology Centre, 97 Lisburn Road, Belfast, BT9 7BL, United Kingdom.

* email: chris.yesson@ioz.ac.uk, phone: +44 2074496267 


\title{
Change in abundance of large brown seaweeds
}

\begin{abstract}
The large brown seaweeds (macroalgae) are keystone species in intertidal and shallow subtidal marine ecosystems and are harvested for food and other products. Recently, there have been sporadic, often anecdotal, reports of local abundance declines around the British Isles, but regional surveys have rarely revisited sites to determine possible changes. An assessment of changes in the abundance of large brown seaweeds around the British Isles using historical survey data, and determination of whether any changes were linked with climate change was undertaken. Data were analysed from multiple surveys for 14 habitat-forming and commercially important species of Phaeophyceae, covering orders Laminariales, Fucales and Tilopteridales. Changes in abundance were assessed for sites over the period 1974-2010. Trends in distribution were compared to summer and winter sea surface temperatures (SST). Results revealed regional patterns of both increase and decrease in abundance for multiple species, with significant declines in the south for kelp species and increases in northern and central areas for some kelp and wracks. Abundance patterns of 10 of the 14 species showed a significant association with SSTs, but there was a mixture of positive and negative responses. This is the first UK-wide observation of declining abundance of large brown seaweeds. Historical surveys provide useful data to examine trends in abundance, but the ad hoc nature of these studies limit the conclusions that can be drawn. Although the British Isles remains a stronghold for large brown algae, it is imperative that systematic surveys are undertaken to monitor changes.
\end{abstract}

\section{Keywords}

Seaweeds; climate change; ecosystem engineers; kelp; fucoids 


\section{Change in abundance of large brown seaweeds}

\section{Introduction}

Seaweed communities in different parts of the world have been profoundly impacted by humans, and in a time of rapid environmental change the large brown seaweeds have been the subject of an increasing number of reports documenting both their decline or loss coupled with an increase in populations of predominantly invasive species (Brodie et al. 2009; Brodie et al. 2014, Koch et al. 2013; Lima et al. 2007; Simkanin et al. 2005). Large brown seaweeds are integral components of marine communities and are the main habitat formers in temperate reef ecosystems (Tuya et al. 2012), with kelp forests (Laminariales) dominating biomass in the subtidal and fucoids (Fucales) in the intertidal. Kelp forests are a major source of primary production and one of the most productive habitats on Earth (Reed et al. 2008). The highly productive fucoids also play a key role in carbon capture and transfer in coastal ecosystems (Gollety et al. 2008). These habitat-forming seaweeds facilitate a diverse community of understory algae, invertebrates and vertebrates (Jørgensen and Christie, 2003). Brown seaweeds are also an economically valuable resource: they were harvested for soda ash and iodine between the $17^{\text {th }}$ and $19^{\text {th }}$ centuries, and remain an important source of alginates (McHugh, 2003; Smale et al. 2013 and refs. therein). More recently, there has been interest in the biochemical properties of macroalgae for potential use in medicine (Wijesinghe and Jeon, 2012), in addition to the potential use of kelps in biofuel production (Roberts and Upham, 2012).

Causes of population level change in large brown seaweed abundance appear to be varied and complex, compounded by the life histories of these seaweeds, for example thermal tolerance changes over different phases of life history (Koch et al. 2013). The geographic distributions of large kelp species (e.g. Laminaria digitata, L. hyperborea, and Saccharina latissima) appear to be limited by summer and winter isotherms (Harley et al. 2012; van den Hoek, 1982, Breeman, 1990) 


\section{Change in abundance of large brown seaweeds}

and some reviews have predicted declines in macroalgal abundance due to environmental change (Harley et al. 2012; Hiscock et al. 2004; Koch et al. 2013; Müller et al. 2009). Some species of macroalgae, such as Alaria esculenta, have been proposed as indicators of biotic response to climate change (Mieszkowska et al. 2006). Given that sea-surface temperatures in the northeast Atlantic have increased by $c a .0 .3-0.8^{\circ} \mathrm{C}$ per decade over the last ca. 25 years (Lima and Wethey 2012), climate change is an important factor influencing coastal seaweed communities (Poloczanska et al. 2013).

In order to determine the extent of change in these seaweed communities, and to relate these changes to environmental influences, long term monitoring and/or reliable quantitative survey evidence from sites which can be resurveyed are required. However, frequently both types of evidence are lacking. Where losses of large brown seaweeds have been reported (Table 1), methods have included revisiting sites with historical surveys, undertaking a literature review, and making inferences from anecdotal evidence. Reported losses of Alaria esculenta in Ireland (Simkanin et al. 2005) and Britain (Mieszkowska et al. 2006) were determined by comparisons of sites with historical data. In the northwest Atlantic, retraction of this species at its southern edge was inferred from a literature review (Merzouk and Johnson, 2011). Losses of Saccharina latissima off the coast of Norway were determined by surveying 660 sites between 2004 and 2009 and making comparisons with a historical dataset (Moy and Christie 2012). For reported losses of Saccharina latissima and Laminaria ochroleuca from the north coast of Spain, sites were resurveyed between 2007 and 2010 to match previous surveys conducted between 1977 and 1978 (Fernández 2011). In contrast, Tuya et al. (2012), who compared cold and warm water assemblages along the Portuguese coast, inferred that Laminaria hyperborea had retreated from its southern edge based largely on anecdotal and personal observations over recent decades. 
The British Isles is an important biogeographic transition zone in the temperate region of the northeast Atlantic, and the littoral and shallow sublittoral regions support $c a$. 50\% of the North Atlantic's documented seaweed flora (Yesson et al. in press). The northern and southern limits of the majority of commercially important large brown seaweed species occur outside the British Isles, except for Laminaria ochroleuca, which is at its northern limit in England, and Alaria esculenta whose southern limit is just into northern France (although the limits of A. esculenta and L. digitata in France occur at the same isotherm as southern England). Seaweeds have been recorded for over 250 years and the first broad-scale survey of macroalgal populations to use a modern abundance scale classification was conducted over half a century ago by Crisp and Southward (1958) who pioneered a categorical classification of abundance defined by percentage cover thresholds based on a semi-logarithmic scale. This scale came to be known by the initials of the categories (ACFOR Abundant, Common, Frequent, Occasional and Rare) (Crisp and Southward, 1958). Variants of this classification of abundance have been used regularly in surveys of the British and Irish coastlines. Although additional categories, such as dominant and superabundant, have been incorporated into the scale, and thresholds defining the categories have varied slightly, this system has remained in common use for coastal surveys (Hiscock, 1996; Mieszkowska et al. 2006; Wijesinghe and Jeon, 2012).

The ACFOR surveys of Crisp and Southward (1958) were repeated 45 years later to determine change in abundance of intertidal species around Ireland (Simkanin et al. 2005). Simkanin et al. (2005) found that three kelp species (A. esculenta, L. digitata and S. latissima) had declined significantly in abundance between 1958 and 2003. An equivalent systematic examination of 


\section{Change in abundance of large brown seaweeds}

changes in macroalgal abundance has not been undertaken in Britain, despite sporadic (often anecdotal) reports of population declines for some species and locations.

Between the 1970s and 2000s, there have been several substantial coastal seaweed surveys around the British Isles (Smale et al. 2013), but often these efforts have been regionally focussed, and there is no ongoing strategy to perform long term monitoring at a national level. Our aim is to combine existing survey data spanning the past four decades in order to examine spatial and temporal trends in the abundance of large brown seaweeds in relation to changing climate.

\section{Methods}

\section{Distribution data}

A database of 127,569 observations (covering the $18^{\text {th }}$ century to the present day) of large brown macroalgae around the British Isles was collated by Yesson et al. (in press). These data were collected from a variety of sources, including national and regional surveys, museum databases and literature searches. The majority of data was accessed via the National Biodiversity Network Gateway and the Marine Recorder project. These data cover 15 commercially important species of kelp, fucoids and related species: the Laminariales Alaria esculenta, Chorda filum, Laminaria digitata, L. hyperborea, L. ochroleuca, Saccharina latissima, Undaria pinnatifida, Tilopteridales Saccorhiza polyschides and the Fucales Ascophyllum nodosum, Fucus serratus, F. spiralis, F. vesiculosus, Himanthalia elongata, Pelvetia canaliculata and the non-native Sargassum muticum. (Although documented in the original database, the alien species $U$. pinnatifida was not included in this study due to insufficient data, reducing the species list to 14). These data were filtered to include only those records with species' abundance data and a spatial accuracy of $1 \mathrm{~km}$ or better. 


\section{Change in abundance of large brown seaweeds}

These data record abundance using variants of the ACFOR scale (Crisp and Southward, 1958). A summary of the categories used by various surveys is presented in Table 2 along with our method to integrate these into a single 5-level system (Abundant, Common, Occasional, Rare and Not recorded - ACORN). Given the discrepancies around the Occasional and Frequent categories in the original classifications, these were combined in order to reduce categorical mismatches. Upon examination of the data, it was found that very few surveys recorded the absence of a species, so the Not recorded category was omitted.

Observations of species presence were grouped onto a $1 \mathrm{~km}$ grid, where multiple observations within the same grid and time period were treated as a single observation, with the abundance recorded as the mean of all observations rounded to the nearest integer, using a numerical coding of the classification scheme (4=Abundant, $3=$ Common, etc). Data were examined regionally based on the biogeographic boundaries described by the Joint Nature Conservation Committees regional seas project (Connor et al. 2006).

\section{Sea surface temperatures}

High resolution data of sea surface temperatures (SSTs) were downloaded from the "Ocean Color Web" portal (http://oceancolor.gsfc.nasa.gov/) on grids of 2.5 arc minute resolution. Level 3 monthly mean SST data were processed into annual mean summer and winter layers for the period 2003-2010. As temperature data for earlier periods are not available at such high resolution, a lower resolution dataset was obtained and scaled up to match the high resolution data (Hijmans et al. 2005). Low resolution SST data were obtained from "HadISST", the Hadley Centre Sea Ice and Sea Surface Temperature data set (Rayner, 2003). The HadISST dataset contains global grids of monthly mean SST values at 1 arc degree resolution covering the period 1871 to the present. 


\section{Change in abundance of large brown seaweeds}

Annual summer and winter layers were generated by calculating the mean of April to September temperatures for summer and October to the following March for winter (so winter of year $\mathrm{N}$ incorporates the last quarter of year $\mathrm{N}$ and the first quarter of year $\mathrm{N}+1$ ). These layers were rescaled onto a higher resolution grids by creating difference layers constructed by subtracting present-day values (mean of years 2003-2010) from the required time period (i.e. 1974). This difference layer was then added to a high resolution layer from the present day, in order to generate a high resolution layers for all years of this study. This follows the methodology employed in the construction of the worldclim future and past climate data (Hijmans et al. 2005) described in (http://www.worldclim.org/downscaling). Finally, the rescaled high resolution layers were reprojected onto the Ordnance Survey of Great Britain 1936 grid (epsg:27700), using grid dimensions approximately matching the MODIS layers $(3 \mathrm{~km}$ x $3 \mathrm{~km})$. Processing of GIS layers were achieved using the statistical software R (R Core Team, 2013), with package "raster" v3.0.2 (http://CRAN.Rproject.org/package=raster), and tools from the Geodata Abstraction Library - "gdal” v1.10.1 (http://www.gdal.org/).

\section{Analysis}

Observations of abundance were grouped within years into summer (April-September) and winter (October-March) observations. Only observations from the same season were compared across years to minimise the impact of seasonal variation on trend lines. Rate of change of abundance was calculated for each site using linear regression. Correlation of change in abundance was tested for each pair of species using the Pearson correlation coefficient with data from sites were both species were present.

A generalised linear mixed model was used to test the influence of sea surface temperature on abundance. The response variable, abundance, was coded as 1-4 (1-Rare, 4-Abundant); fixed effects 


\section{Change in abundance of large brown seaweeds}

were summer and winter sea surface temperatures of the year of observation, which were input as both linear and quadratic terms; year of observation was regarded as a random effect as the response to temperature is expected to be consistent over the time of observations; and a spatial correlation structure based on the linear distance between sites was included to correct for spatial autocorrelation. A model was fitted for each species using the glmmPQL function from the R package MASS (Venables and Ripley, 2002).

\section{Results}

The database of species observations with abundance data contained 76,527 entries. Spatially inaccurate records were removed and the remaining data aggregated by decade and paired by overlapping locations (i.e. records located within the same $1 \mathrm{x} 1 \mathrm{~km}$ square on the ordnance survey grid), leaving 5,481 abundance observations for the 14 species. Site observations were 1-36 years apart between 1974 and 2010. The majority of sites (74\%) had only two temporal observations per species, and only $3 \%$ of sites had more than 4 temporal observations for any species. The typical time period between observations was 1 year (11\%), but the majority of sites had observations more than a decade apart, and the median temporal difference between observations was 11 years. The most frequently observed abundance class was "Common", which accounted for $42 \%$ of observations.

Examining abundance observations by site between 1974 and 2010 (Table 3) revealed that for all species, except Laminaria ochroleuca, there were more sites showing an increase in abundance than a decline. Five species, Chorda filum, Laminaria ochroleuca, Saccharina latissima, Fucus serratus and $F$. spiralis showed a negative trend in abundance. Comparing abundance trends between 


\section{Change in abundance of large brown seaweeds}

species, there were 25 pairs of species that showed significant correlations (Table 4). Nineteen of these significant correlations were positive, indicating that it is common for multiple species to either increase or decrease in tandem at a particular site. The greatest negative correlation was between $F$. serratus and $A$. nodosum.

Examining patterns by biogeographical region (Fig. 1a, b, Table 5), shows disparate changes for kelps (Fig. 1a) and wracks (Fig. 1 b). The general trend for kelps was a decrease in abundance in the southern geographic regions, and relatively stability or an increase in abundance in the northern regions. Species with a marked contrast between regions (red to green, Table 5) included Chorda filum and L. hyperborea (decrease in the English Channel versus increase in the Irish Sea), and Saccorhiza polyschides (decrease in the Western Channel and Celtic Sea versus increase in the Irish Sea). In contrast, the wracks showed an insignificant decline in Western Scotland, but $F$. vesiculosus and A. nodosum had strong increases in Northeast England (North Sea). Only one species, Sargassum muticum, revealed a significant decrease in the south (Western Channel \& Celtic Sea) and a significant increase in the west (Irish Sea).

Regional Sea Surface Temperatures (SSTs) showed annual fluctuations between 1974-2010 (Fig. 2). The general trend has been a $1-2{ }^{\circ} \mathrm{C}$ increase during this time period, with the East coast (North Sea) experiencing the greatest increases. Regions with the least change were West Ireland and Western Scotland (Table 5). For several species, L. digitata, L. hyperborea, F. vesiculosus, Pelvetia canaliculata and S. muticum, abundance was positively correlated with summer temperature, and of those, $F$. vesiculosus and $S$. muticum abundances were also positively correlated with winter temperature (Table 5 \& Table S1; Supplementary material). In contrast, abundance of L. digitata 


\section{Change in abundance of large brown seaweeds}

and L. hyperborea were negatively correlated with winter temperature. Only abundance of Saccharina latissima responded negatively to both summer and winter temperatures. Species' abundances which were only negatively correlated with winter temperature were $F$. spiralis and Himanthalia elongata.

\section{Discussion}

Here, for the first time, we have demonstrated change in abundance in the large brown seaweeds of the British Isles using a comprehensive and novel meta-analysis approach. There is an expectation that climate change will lead to changing distributions for many coastal species (Harley et al. 2006; Koch et al. 2013). However, this study did not establish a clear, replicated pattern of association between areas of decline and greater changes of SST. There is a striking difference in biogeographic signal: in the south, several species have declined significantly compared to central and northern regions where they have remained relatively stable or shown a significant increase (C. filum, $L$. hyperborea, S. polyschides). The kelps, which are predominantly subtidal, appear to have declined more than the intertidal wracks. These observations support the prediction in Brodie et al. (2014) that there will be significant changes in the distribution and composition large brown seaweeds, but the role of temperature as the main driver of change is not clear. For some species (i.e. $F$.

vesiculosus, A. nodosum, C. filum), , warmer summer and winter temperatures appear favourable, but for $5 / 14$ species abundance is negatively correlated with winter temperature (Table 5 ), which may be cause for concern in a time of rapid warming.

There are two species, L. digitata and L. hyperborea, that show a conflicting pattern of temperature and abundance: both show a positive correlation to summer temperature, but a negative response to 


\section{Change in abundance of large brown seaweeds}

warmer winter temperatures. However, the abundance of L. digitata has increased significantly in the northern North Sea, the region in the British Isles that has seen the largest temperature rises over the last 30 years. In contrast, L. hyperborea shows a significant decrease in abundance in the English Channel and a significant increase in abundance in the Irish Sea. Conflicting seasonal patterns may be driven by the conditions required for the initiation and development of different life history stages. L. digitata is a summer fertile species and Bartsch et al. (2013) have shown that for Helgoland populations, sporogenesis is a cold adapted process with the narrowest temperature window of all the reproductive stages, with an optimum at $5-10^{\circ} \mathrm{C}$. In contrast to L. digitata, $L$. hyperborea is fertile in winter and early spring (Müller et al. 2008). For optimum development, gametophytes require temperatures up to $14-15^{\circ} \mathrm{C}$ (Lüning 1990). Therefore, whilst warmer temperatures may favour some aspects of the life history, they may negatively affect sporogenesis in L. digitata and gametogenesis in L. hyperborea. Short term fluctuations in temperature may also cause changes in abundance. For example, short term declines in abundance were observed in SW Scotland after a period of extreme cold, coinciding with spring tides (Todd and Lewis 1984) but such events will not necessarily influence long term trends. Declines have also been reported on the Atlantic coast of France (Cosson, 1999), coincident with increases in abundance of S. muticum.

Laminaria ochroleuca, in contrast to L. digitata, and L. hyperborea, is a warm water species, first recorded in UK waters in the middle of the $20^{\text {th }}$ century (Parke, 1948), reaching its northern limit in the UK (John 1969) and is an example of a range-expansion species. Although abundance was not significantly related to temperature in the summer or winter, this species showed a significant decline in abundance in the W. English Channel \& Celtic Sea. However, data are limited for the first decade of this study and spatially clustered around Plymouth and the Scilly Isles. It has been reported that elevated UV radiation may negatively impact on both zoospores (Wiencke et al. 2000) 


\section{Change in abundance of large brown seaweeds}

and sporophytes of L. ochroleuca (Roleda et al. 2006), but there was no significant pattern associated with changing SST. Pereira et al. (2011) suggested that L. ochroleuca may be outcompeted by Saccorhiza polyschides in northern populations but we found no significant correlation between changing abundance of these species. The observed decline is contrary to expectation of increased abundance and northward spread for this warmer-water, range-expanding species in light of increasing temperatures (Hiscock et al. 2004).

There is evidence for a north-south divide for some species, with southern populations showing declines but increases evident further north. Two such examples are Chorda filum and $S$. polyschides. Chorda filum is an amphi-oceanic cold-water species, tolerant of high sedimentation and reduced salinity and shows a significant decline in the English Channel. S. polyschides is a kelp of temperate waters with a relatively restricted distribution (Lüning 1990) that appears to be declining in the W. Channel \& Celtic Sea. Both species show an increase in the Irish Sea and relative stability further north. The decrease of abundance in C. filum may be influenced by temperatures in the south being too high for gametogenesis, which occurs in autumn at temperatures between 5 and $10^{\circ} \mathrm{C}$, with $15^{\circ} \mathrm{C}$ halting reproduction completely (Lüning 1990). Although the relationship with temperature differs, L. hyperborea has the same pattern of abundance as C. filum, reflecting their optimum environmental requirements ('comfort zone'). Although S. polyschides is a warmer water species than C. filum, temperature is a critical determinant of zoospores viability, gametophyte fertility and juvenile sporophyte survival. Sporophytes appear from spring to summer, but later recruits tend not to survive in warmer southern areas.

Amongst the wracks, Sargassum muticum shows a similar pattern of abundance as the kelp species Saccorhiza polyschides, although the significant increase in the Irish Sea was much greater than the 


\section{Change in abundance of large brown seaweeds}

significant decrease in the W. English Channel \& Celtic Sea. However, the positive association with both summer and winter temperatures is skewed by a smaller dataset for this species, which was first reported for the UK on the south coast of England in 1971 (Farnham et al. 1973) and has spread north since that time. The significant increase in the Irish Sea is a reflection of its northward movement.

Many wracks demonstrated a weakly negative trend in Western Scotland, although (with the exception of $S$. muticum) the only significant trends were increases in abundance for Fucus serratus, F. vesiculosus and Ascophyllum nodosum. A. nodosum and F. vesiculosus showed significant increases in the North Sea and both species showed a positive association with temperature, a pattern in keeping with anecdotal reports from the area, but we note that this region has limited temporal sampling and these results are predominantly determined by data from two years. F. serratus increased in W. English Channel \& Celtic Sea, but there was no pattern between abundance and temperature. The remaining wracks showed no significant regional trends, although the abundance of both $F$. spiralis and Himanthalia elongata had a negative correlation with winter temperatures, which may be a concern if the trend for milder winters continues.

Temperature is expected to be a factor in species declines at the edge of ranges, where those species are at the limit of their thermal tolerances (i.e. southern edge for northern hemisphere species) (Harley et al. 2006). Of the 14 species in this study, none are at their southern limits in the British Isles. However, the Arctic and cold temperate species Alaria esculenta has its southern limit at approx. the $20^{\circ} \mathrm{C}$ August isotherm (Widdowson 1971) and is only found in restricted locations in Northern France (Lüning, 1990). Although studies have shown declines of this species in the northeast Atlantic (Merzouk and Johnson, 2011; Mieszkowska et al. 2006; Simkanin et al. 2005), 


\section{Change in abundance of large brown seaweeds}

our data show no significant relationship in change in abundance with summer or winter temperature. However, this is the only species to show a significant increase in abundance in Western Scotland, and may be an example of a species flourishing in its optimum environment. tom Dieck (1993) reported that A. esculenta zoospores have an upper limit of $18{ }^{\circ} \mathrm{C}$ and optimal germination between 2 and $12{ }^{\circ} \mathrm{C}$ whereas gametophytes are more temperature tolerant with an upper survival limit of $19-21^{\circ} \mathrm{C}$. A. esculenta is proposed as an indicator species for monitoring the effects of climate change in Britain and Ireland (Mieszkowska et al. 2006). Therefore, although we did not find evidence of a significant change in abundance in Britain, the cooler temperatures required for zoospores may ultimately restrict this species in the region if temperatures continue to increase.

\section{Study design}

The results reported here are dependent on the assumption that the paired observations of abundance are comparable. These data were collected 1-36 years apart, by a variety of researchers with potentially different objectives and survey methodologies. However, all had the objective of measuring macroalgal abundance, and the abundance scales employed in these surveys were very similar. Although it is possible that there is a systematic bias in the data that we have not appreciated, the authors' experience covering many decades of field surveys, and discussions with other researchers, leads us to believe that these are valid comparisons.

It could be argued that because the majority of site-specific trends (4056) are based on 2 years of observations, that it is difficult to determine a robust site-specific trend. We expect fluctuations in abundance that may not reflect a long term trend, for example, $50 \%$ of species absences in north Norfolk were found to be ephemeral (Tittley, 1998). Nevertheless a significant portion of sites 
(1125) have data from more than two time periods. Our objective is not to examine site-specific trends but to combine these to present regional and country-wide patterns. Given the size and extensive regional and temporal sampling, and the broad agreement with results already reported (Table 1), we consider that our findings are noteworthy and are a foundation for further work and discussion.

Although this study examines average climatic conditions, extreme events may be driving some population declines (Smale and Wernberg, 2013). Additionally, there are many factors not considered in this study that have been identified as stressors on macroalgal populations, such as pollution and eutrophication (Coelho et al. 2000), rising atmospheric $\mathrm{CO}_{2}$ (Brodie et al. 2014) and increasing herbivory from urchins (Steneck et al. 2002).

Historical surveys are useful sources of data for examining long-term trends. However, there are limitations on what can be interpreted from this ad hoc collection of surveys, and it is important to understand these limitations. Sophisticated time series analyses (i.e. Pinsky et al. 2013) rely on multiple repeated sampling of the same sites, which are not available for our data. The observations are temporally biased and the median difference between observations is 11 years, which means we cannot replicate analyses such as those relying on year on-year transitional models (Mieszkowska et al. 2013). Methodological advances are required in order to extract the full potential from these data. 


\section{Change in abundance of large brown seaweeds}

\section{Conclusions}

Large brown seaweeds are habitat-forming and fundamental to the functioning of coastal marine ecosystems and the British Isles. Long term trends of change in abundance for large brown seaweeds present serious challenges to the long term future of these ecosystems, particularly as the British Isles is in the centre of the NE Atlantic distributions for most species and not at climatic tolerance limits. Given that temperature alone does not explain all observed increases and decreases in abundance, it is vital to identify both the physical and biological factors that are driving these changes. In addition, a much greater understanding of the different phases of the life history of these species across the population spectrum is required, along with consideration of such factors as increased storminess, turbidity and pollution.

Historical surveys can be useful to examine long term trends in changing abundance, but these data are no substitute for systematic, repeated studies, and the ad hoc nature of sampling can greatly limit our conclusions. At present, population abundances are typically classified as common, but some areas appear to show climate-linked declines. These declines must be monitored to ascertain whether they are ongoing, and if so studied to uncover causes, particularly in reference to potential loss of genetic diversity. This is best achieved by a long term monitoring programme.

Large brown seaweeds were a significant omission from the recent "State of Nature", a report documenting population declines for many species in the UK (Burns et al. 2013). The data presented here suggest that some of these brown seaweeds should be added to the list of declining species for some regions and awareness raised given the important given the habitat they create. 
Change in abundance of large brown seaweeds

\section{Acknowledgements}

This research was funded by The Crown Estate. We are grateful to Ian Tittley, Keith Hiscock and Martin Wilkinson for advice and information on historical surveys. 


\section{References}

Andersen GS, Steen H, Christie H, Fredriksen S, Moy FE (2011). Seasonal patterns of sporophyte growth, fertility, fouling, and mortality of Saccharina latissima in Skagerrak, Norway: implications for forest recovery. J Mar Biol 2011:1-8

Bartsch I, Vogt J, Pehlke C, Hanelt D (2013). Prevailing sea surface temperatures inhibit summer reproduction of the kelp Laminaria digitata at Helgoland (North Sea). J Phycol 49:1061-1073

Breeman AM (1990) Expected effects of changing seawater temperatures on the geographic distribution of seaweed species. In: Beukema, JJ, Wolff WJ, Brouns JJWM. Expected effects of climatic change on marine coastal ecosystems. Springer, Netherlands. pp 69-76.

Brodie J, Andersen RA, Kawachi M, Millar AJK (2009) Endangered algal species and how to protect them. Phycologia 48:423-438

Brodie J, Williamson C, Smale D et al. (2014) The future of the NE Atlantic benthic flora in a high $\mathrm{CO}_{2}$ world. Ecol Evol 4:2787-2798

Burns F, Eaton M, Gregory R, et al. (2013) State of Nature report. The State of Nature Partnership

Coelho S, Rijstenbil J, Brown M (2000) Impacts of anthropogenic stresses on the early development stages of seaweeds. J Aquat Ecosyst Stress Recover 7:317-333

Connor D, Allen J, Golding N (2004) The marine habitat classification for Britain and Ireland, version 04.05. JNCC, Peterborough

Cosson J (1999) On the progressive disappearance of Laminaria digitata on the coasts of Calvados (France). Cryptogam Algol 20:35-42

Crisp D, Southward A (1958) The distribution of intertidal organisms along the coasts of the 
Change in abundance of large brown seaweeds

English Channel. J Mar Biol Assoc United Kingdom 37:157-208

Davies A, Johnson M, Maggs C (2007) Limpet grazing and loss of Ascophyllum nodosum canopies on decadal time scales. Mar Ecol Prog Ser 339:131-141

Eriksson BK, Johansson G, Snoeijs P (2002). Long-term changes in the macroalgal vegetation of the inner Gullmar Fjord, Swedish Skagerrak coast. J Phycol 38:284-296

Farnham WF, Fletcher RL, Irvine LM (1973) Attached Sargassum found in Britain. Nature 243:231-232

Fernández C (2011) The retreat of large brown seaweeds on the north coast of Spain: the case of Saccorhiza polyschides. Eur J Phycol 46:352-360

Fernández C, Niell FX (1982). Patterns of zonation in rocky inter-tidal shores at Cape_Penas region (Astuies, $\mathrm{N}$ of Spain). Investigacion Pesquera 46:121-141

Gollety C, Migne A, Davoult D (2008) Benthic metabolism on a sheltered rocky shore: role of the canopy in the carbon budget. J Phycol 44:1146-1153

Harley CDG, Anderson KM, Demes KW, et al. (2012) Effects of Climate Change on Global Seaweed Communities. J Phycol 48:1064-1078

Harley CDG, Randall Hughes A, Hultgren KM, et al. (2006) The impacts of climate change in coastal marine systems. Ecol Lett 9:228-241

Harries DB, Harrow S, Wilson JR, Mair JM, Donnan DW (2007). The establishment of the invasive alga Sargassum muticum on the west coast of Scotland: a preliminary assessment of community effects. J Mar Biol Assoc UK 87:1057-1067

Hijmans RJ, Cameron SE, Parra JL, et al. (2005) Very high resolution interpolated climate surfaces for global land areas. Int J Climatol 25:1965-1978 


\section{Change in abundance of large brown seaweeds}

Hiscock K (1996) Marine nature conservation review: rationale and methods. JNCC, Peterborough

Hiscock K, Southward A, Tittley I, Hawkins S (2004) Effects of changing temperature on benthic marine life in Britain and Ireland. Aquat Conserv Mar Freshw Ecosyst 14:333-362

John DM (1969) An Ecological Study on Laminaria ochroleuca. J Mar Biol Assoc UK 49:175-187

Jørgensen NM, Christie H (2003) Diurnal, horizontal and vertical dispersal of kelp-associated fauna. Hydrobiologia 503:69-76

Jueterbock A, Coyer JA, Tyberghein L, Olsen JL, Hoarau G (2012) Responses of the macroalgal key species Fucus serratus: driving the impact of climate change on North Atlantic rocky shores. The Phycologist 83:18-19

Koch M, Bowes G, Ross C, Zhang X-H (2013) Climate change and ocean acidification effects on seagrasses and marine macroalgae. Glob Chang Biol 19:103-132

Lima FP, Ribeiro PA, Queiroz N, et al. (2007) Do distributional shifts of northern and southern species of algae match the warming pattern? Glob Chang Biol 13:2592-2604

Lima FP, Wethey DS (2012) Three decades of high-resolution coastal sea surface temperatures reveal more than warming. Nat Commun 3:704

Lüning K (1990) Seaweeds: their environment, biogeography, and ecophysiology. Wiley, New York

McHugh D (2003) A guide to the seaweed industry. Food and Agriculture Organisation of the United Nations, Rome

Merzouk A, Johnson LE (2011) Kelp distribution in the northwest Atlantic Ocean under a changing climate. J Exp Mar Bio Ecol 400:90-98

Mieszkowska N, Kendall M., Hawkins SJ, et al. (2006) Changes in the Range of Some Common 
Change in abundance of large brown seaweeds

Rocky Shore Species in Britain - A Response to Climate Change? Hydrobiologia 555:241251

Mieszkowska N, Milligan G, Burrows MT, et al. (2013) Dynamic species distribution models from categorical survey data. J Anim Ecol 82:1215-1226

Morizur Y (2001) Changements climatiques ou sur exploitation? Gros temps sur les algues brunes. Les nouvelles de l'Ifremer 25:1

Moy FE, Christie H (2012) Large-scale shift from sugar kelp ( Saccharina latissima ) to ephemeral algae along the south and west coast of Norway. Mar Biol Res 8:309-321

Müller R, Laepple T, Bartsch I, Wiencke C (2009) Impact of oceanic warming on the distribution of seaweeds in polar and cold-temperate waters. Bot Mar 52:617-638

Müller R, Wiencke C, Bischof K (2008) Interactive effects of UV radiation and temperature on microstages of Laminariales (Phaeophyceae) from the Arctic and North Sea. Clim Res 37:2032113

Parke M (1948) Laminaria ochroleuca de la Pylaie Growing on the Coast of Britain. Nature $162: 295-296$

Pearson GA, Lago-Leston A, Mota C (2009) Frayed at the edges: selective pressure and adaptive response to abiotic stressors are mismatched in low diversity edge populations. J Ecol 97:450462

Pehlke C, Bartsch I (2008) Changes in depth distribution and biomass of sublittoral seaweeds at Helgoland (North Sea) between 1970 and 2005. Clim Res 37:135-147

Pereira TR, Engelen AH, Pearson GA, et al. (2011) Temperature effects on the microscopic haploid stage development of Laminaria ochroleuca and Sacchoriza polyschides, kelps with 
Change in abundance of large brown seaweeds

contrasting life histories. Cah Biol Mar 52:395-403

Pinsky ML, Worm B, Fogarty MJ, et al. (2013) Marine taxa track local climate velocities. Science $341: 1239-1242$

Poloczanska, ES, Brown, CJ, Sydeman, WJ, et al. (2013). Global imprint of climate change on marine life. Nature Climate Change 3: 919-925.

R Core Team (2013) R: A Language and Environment for Statistical Computing. R Foundation for Statistical Computing, Vienna, Austria

Rayner NA (2003) Global analyses of sea surface temperature, sea ice, and night marine air temperature since the late nineteenth century. J Geophys Res 108:4407

Reed DC, Rassweiler A, Arkema, KK (2008) Biomass rather than growth rate determines variation in net primary production by giant kelp. Ecology 89:2493-2505

Roberts T, Upham P (2012) Prospects for the use of macro-algae for fuel in Ireland and the UK: An overview of marine management issues. Mar Policy 36:1047-1053

Roleda M, Dethleff D (2011) Storm-generated sediment deposition on rocky shores: Simulating burial effects on the physiology and morphology of Saccharina latissima sporophytes. Mar Biol Res 7:213-223

Roleda MY, Hanelt D, Wiencke C (2006) Exposure to ultraviolet radiation delays photosynthetic recovery in Arctic kelp zoospores. Photosynth Res 88:311-322

Simkanin C, Power AM, Myers A, et al. (2005) Using historical data to detect temporal changes in the abundances of intertidal species on Irish shores. J Mar Biol Assoc UK 85:1329-1340

Smale DA, Burrows MT, Moore P, et al. (2013) Threats and knowledge gaps for ecosystem services provided by kelp forests: a northeast Atlantic perspective. Ecol Evol 3:4016-4038 


\section{Change in abundance of large brown seaweeds}

Smale DA, Wernberg T (2013) Extreme climatic event drives range contraction of a habitatforming species. Proc R Soc B-Biological Sci 280:20122829

Steneck RS, Graham MH, Bourque BJ, et al. (2002) Kelp forest ecosystems: biodiversity, stability, resilience and future. Environ Conserv 29:436-459

Tittley I (1998) Medium to Long-Term Studies on the Rocky Shore Vegetation of North Norfolk. In: Scott G, Tittley I (eds) Chang. Mar. Flora North Sea. CERCI, Scarborough, pp 53-64

Todd CD, Lewis JR (1984) Effects of low air temperature on Laminaria digitata in south-western Scotland. Mar Ecol Prog Ser 16:199-201

tom Dieck, I (1993) Temperature tolerance and survival in darkness of kelp gametophytes (Laminariales, Phaeophyta): ecological and biogeographical implications. Mar Ecol Prog Ser 100:253-264

Tuya F, Cacabelos E, Duarte P, et al. (2012) Patterns of landscape and assemblage structure along a latitudinal gradient in ocean climate. Mar Ecol Prog Ser 466:9-19

Van den Hoek C (1982) The distribution of benthic marine algae in relation to the temperature regulation of their life histories. Biol J Linn Soc 18:81-144

Venables WN, Ripley BD (2002) Modern Applied Statistics with S, Fourth. Springer, Berlin

Widdowson TB (1971) A taxonomic revision of the genus Alaria Greville. Syesis 4:11-49

Wiencke C, Gomez I, Pakker H (2000) Impact of UV-radiation on viability, photosynthetic characteristics and DNA of brown algal zoospores: implications for depth zonation. Mar Ecol Prog Ser 197:217-229

Wijesinghe W, Jeon Y (2012) Biological activities and potential industrial applications of fucose rich sulfated polysaccharides and fucoidans isolated from brown seaweeds: A review. 
Change in abundance of large brown seaweeds

Carbohydr Polym 88:13-20 


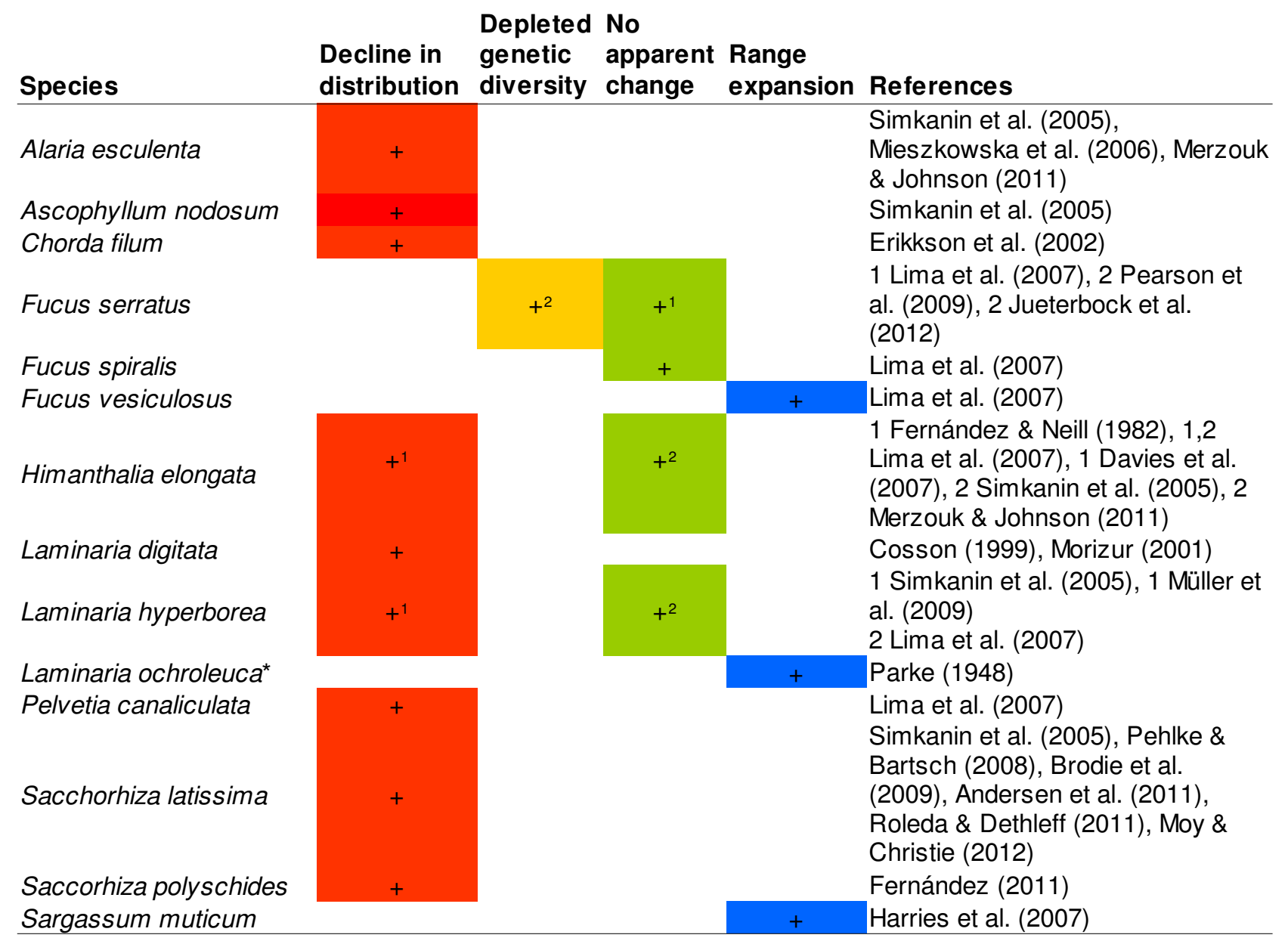

Table 1: Summary of reported changes to key large brown seaweed species. 
Table 2. Summary of abundance scales and how they are used for this study. Group $1=$ JNCC post1990 / MNCR / SNH / EN (MarCLIM and MBA post2006), Group 2 = Seasearch / Yorkshire Naturalists, Group 3 = MBA pre-2006 / CCW. Superscript signifies categories used for this study, ${ }^{\mathrm{A}}$ Abundant (Dark Grey), ${ }^{\mathrm{C}}$ Common (Grey), ${ }^{\mathrm{O}}$ Occasional (Light Grey), ${ }^{\mathrm{R}}$ Rare (White). JNCC=Joint Nature Conservation Committee, $\mathrm{SNH}=$ Scottish Natural Heritage, MBA=Marine Biological Association, CCW=Countryside Council for Wales, MNCR=Marine Nature Conservation Review.

\begin{tabular}{|c|c|c|c|c|}
\hline Class & Group 1 & Group 2 & MarCLIM & Group 3 \\
\hline Suprabundant & $>80 \%{ }^{\mathrm{A}}$ & $>80 \%{ }^{A}$ & & $\begin{array}{r}100 \% \text { cover ano } \\
\text { depth }\end{array}$ \\
\hline Abundant & $40-79 \%{ }^{A}$ & $40-80 \%{ }^{A}$ & $>30 \%{ }^{A}$ & $>75 \%^{\circ}$ \\
\hline Common & $20-39 \%$ C & $20-40 \% c$ & $5-30 \%{ }^{\mathrm{C}}$ & $20-75 \%^{\circ}$ \\
\hline Frequent & $10-19 \% c$ & $10-20 \% c$ & $<5 \%$ R & $\begin{array}{l}10-19 \% \text { (probably } \\
\text { zone forming but not } \\
\text { so much cover) }\end{array}$ \\
\hline Occasional & $5-9 \% \circ$ & $5-10 \% \circ$ & $\begin{array}{r}\text { Scattered } \\
\text { individuals }{ }^{\mathrm{R}}\end{array}$ & $\begin{array}{r}(5-9 \% ?) \text { a feu } \\
\text { encounters }\end{array}$ \\
\hline Rare & $1-5 \%^{R}$ & $<5 \%^{\mathrm{R}}$ & $\begin{array}{r}\text { Few plants } \\
30 \text { min } \\
\text { search }^{R}\end{array}$ & $(<5 \%)$ rare ${ }^{\mathrm{R}}$ \\
\hline
\end{tabular}


Table 3. Number of observations of species abundance during the period 1974-2010. Sites are $1 \mathrm{~km}^{2}$ regions with 2 or more observations of the same species over this period. The terms decline, stable and increase indicate the number of sites (proportion in parentheses) showing that trend of abundance. Slope indicates the mean value of the slope of abundance change over all sites. Temporal range is the time period for which specific species have data.

\begin{tabular}{llrrrrrrr} 
Group & Species & Obs. & Sites & Decline & Stable & Increase & Slope $\begin{array}{r}\text { Temporal } \\
\text { Range }\end{array}$ \\
\hline Kelp & Alaria esculenta & 130 & 59 & $22(0.37)$ & $3(0.05)$ & $34(0.58)$ & $0.1221974-2010$ \\
& Chorda filum & 391 & 171 & $54(0.32)$ & $4(0.02)$ & $113(0.66)$ & $-0.0291974-2010$ \\
& Laminaria digitata & 435 & 183 & $63(0.34)$ & $3(0.02)$ & $117(0.64)$ & $0.0451974-2010$ \\
& Laminaria hyperborea & 1,283 & 496 & $187(0.38)$ & $8(0.02)$ & $301(0.61)$ & $0.0071974-2010$ \\
& Laminaria ochroleuca & 78 & 29 & $16(0.55)$ & $0(0.00)$ & $13(0.45)$ & $-0.0601978-2010$ \\
& Saccharina latissima & 1,050 & 451 & $176(0.39)$ & $13(0.03)$ & $262(0.58)$ & $-0.0121974-2010$ \\
& Saccorhiza polyschides & 308 & 121 & $44(0.36)$ & $5(0.04)$ & $72(0.60)$ & $0.0041975-2010$ \\
\hline Total & Kelp & 3,675 & 1,510 & $562(0.37)$ & $36(0.02)$ & $912(0.60)$ & - \\
\hline Wracks & Ascophyllum nodosum & 281 & 124 & $48(0.39)$ & $2(0.02)$ & $74(0.60)$ & $0.0331974-2010$ \\
& Fucus serratus & 471 & 198 & $73(0.37)$ & $5(0.03)$ & $120(0.61)$ & $-0.0071974-2010$ \\
& Fucus spiralis & 196 & 84 & $32(0.38)$ & $2(0.02)$ & $50(0.60)$ & $-0.0311974-2010$ \\
& Fucus vesiculosus & 394 & 173 & $59(0.34)$ & $2(0.01)$ & $112(0.65)$ & $0.0611974-2010$ \\
& Himanthalia elongata & 130 & 53 & $21(0.40)$ & $3(0.06)$ & $29(0.55)$ & $0.0031974-2010$ \\
& Pelvetia canaliculata & 244 & 103 & $44(0.43)$ & $2(0.02)$ & $57(0.55)$ & $0.0011974-2010$ \\
& Sargassum muticum & 90 & 37 & $14(0.38)$ & $1(0.03)$ & $22(0.59)$ & $0.0421976-2010$ \\
\hline Total & Wracks & 1,806 & 772 & $291(0.38)$ & $17(0.02)$ & $464(0.60)$ & - \\
\hline Total & Kelp + Wracks & 5,481 & 2,282 & $853(0.37)$ & $53(0.02)$ & $1,376(0.60)$ & - \\
\hline
\end{tabular}


Table 4. Correlation of rate of change in abundance between species. Upper right triangle is Pearson correlation coefficient with significance indicated by: $* * * \mathrm{p}<0.001, * * \mathrm{p}<0.01, * \mathrm{p}<0.05$. Lower triangle is number of sites with both species

present.

\begin{tabular}{|c|c|c|c|c|c|c|c|c|c|c|c|c|c|c|c|}
\hline Group & Species & A. esc. & C. fil. & L. dig. & L. hyp. & L. och. & S. lat. & S. pol. & A. nod. & F. ser. & F. spi. & F. ves. & H. elo. & P. can. & S. mut. \\
\hline \multirow[t]{7}{*}{ Kelp } & Alaria esculenta & - & -0.75 & $0.62^{* *}$ & 0.25 & -0.12 & 0.27 & 0.03 & 0 & 0.05 & -0.2 & -0.24 & -0.3 & $0.97^{* \star *}$ & 0 \\
\hline & Chorda filum & 3 & - & 0.03 & -0.1 & 0 & $0.40^{\star * *}$ & 0.06 & -0.24 & -0.02 & 0.19 & -0.13 & 0.19 & -0.03 & 0.26 \\
\hline & Laminaria digitata & 20 & 32 & - & $-0.24^{*}$ & 0.36 & -0.04 & -0.07 & $0.52^{* *}$ & $0.41^{* \star *}$ & 0.02 & $0.72^{\star \star \star}$ & $0.50^{\star *}$ & -0.3 & 0.57 \\
\hline & Laminaria hyperborea & 49 & 50 & 98 & - & -0.05 & $0.35^{\star \star \star}$ & -0.12 & 0.08 & $0.42^{\star \star \star}$ & -0.12 & 0 & $0.52^{\star *}$ & -0.17 & 0.01 \\
\hline & Laminaria ochroleuca & 3 & 1 & 5 & 27 & - & $-0.88^{*}$ & 0.18 & 0 & 0 & 0 & 0 & $1.00^{*}$ & 0 & 0 \\
\hline & Saccharina latissima & 28 & 119 & 98 & 208 & 5 & - & $0.49^{* * *}$ & 0.16 & -0.13 & 0.34 & 0.14 & -0.26 & -0.03 & -0.29 \\
\hline & Saccorhiza polyschides & 15 & 18 & 37 & 96 & 15 & 73 & - & 0.37 & -0.15 & -0.27 & -0.11 & 0.22 & 0.09 & -0.1 \\
\hline \multirow[t]{7}{*}{ Wrack } & Ascophyllum nodosum & 2 & 29 & 31 & 24 & 0 & 41 & 6 & - & $-0.62^{\star \star \star}$ & $-0.40^{\star *}$ & -0.07 & -0.12 & $0.52^{\star * \star}$ & -0.13 \\
\hline & Fucus serratus & 13 & 43 & 80 & 58 & 0 & 83 & 23 & 85 & - & $0.55^{\star * \star}$ & $0.25^{\star *}$ & $0.68^{* * *}$ & $-0.32^{\star *}$ & 0.14 \\
\hline & Fucus spiralis & 8 & 15 & 26 & 21 & 0 & 30 & 6 & 59 & 63 & - & $0.51^{\star * *}$ & 0.26 & 0.16 & -0.22 \\
\hline & Fucus vesiculosus & 11 & 31 & 50 & 39 & 1 & 53 & 7 & 89 & 117 & 70 & - & $0.82^{\star \star *}$ & 0.16 & $0.89^{* *}$ \\
\hline & Himanthalia elongata & 9 & 8 & 29 & 27 & 3 & 25 & 15 & 12 & 32 & 13 & 16 & - & -0.1 & -0.05 \\
\hline & Pelvetia canaliculata & 8 & 21 & 32 & 23 & 0 & 35 & 6 & 71 & 82 & 65 & 82 & 14 & - & 0.97 \\
\hline & Sargassum muticum & 1 & 18 & 11 & 12 & 1 & 28 & 9 & 8 & 16 & 4 & 7 & 9 & 3 & - \\
\hline
\end{tabular}


Table 5. Summary of the relationship of change in species abundance and sea surface temperature (SST). The central table shows the slope of abundance over time (black lines of Figure 1). Units relate to number of abundance categories per year, so P. canaliculata in Western Scotland has declined approximately one abundance category over the duration of the analysis $(-0.0278 \approx-1 / 36)$. Colours indicate trend and significance. Red indicates an overall negative trend with confidence interval $(\mathrm{CI})$ of trend unambiguously negative. Orange is negative trend, but $\mathrm{CI}$ incorporates a positive response. Green shows unambiguously positive trend, pale green shows positive trend but CI includes negative response. Yellow indicates no significant trend with slope close to zero. ${ }^{*}$ SST change per year is expressed as the slope of the regression line of seasonal mean SST calculated annually from 1974-2010, deeper blue indicates greater change. "Relationship between SST and abundance is based on generalised linear mixed models, + and - indicate the sign of the relationship with the number of symbols indicating the significance (i.e. +++/--- indicates a significant positive/negative relationship of abundance and temperature with $\mathrm{p}<0.001$, similarly $++/--$ signifies $\mathrm{p}<0.01$, and $+/-$

\begin{tabular}{|c|c|c|c|c|c|c|c|c|c|c|c|c|}
\hline \multirow[b]{2}{*}{ Group } & \multirow[b]{2}{*}{ Species } & \multicolumn{3}{|c|}{ South } & \multicolumn{3}{|c|}{ Central } & \multicolumn{3}{|c|}{ North } & \multicolumn{2}{|c|}{$\begin{array}{l}\text { Relationship with } \\
\text { temperature }\end{array}$} \\
\hline & & $\begin{array}{c}\text { SW } \\
\text { Atlantic }\end{array}$ & $\begin{array}{l}\text { W. Channel \& } \\
\text { Celtic Sea }\end{array}$ & $\begin{array}{l}\text { English } \\
\text { Channel }\end{array}$ & $\begin{array}{l}\text { North Sea } \\
\text { (S) }\end{array}$ & Irish Sea & $\begin{array}{l}\text { West } \\
\text { Ireland }\end{array}$ & $\begin{array}{l}\text { North Sea } \\
\text { (N) }\end{array}$ & $\begin{array}{l}\text { Western } \\
\text { Scotland }\end{array}$ & $\begin{array}{l}\text { Scottish } \\
\text { Shelf }\end{array}$ & Summer & Winter \\
\hline \multirow[t]{7}{*}{ Kelp } & Alaria esculenta & & 0.0741 & & & -0.0199 & & -0.0496 & 0.0500 & 0.0001 & & \\
\hline & Chorda filum & & -0.0032 & -0.1500 & & 0.0222 & -0.2500 & & 0.0000 & 0.0001 & & +++ \\
\hline & Laminaria digitata & & 0.0001 & -0.0013 & & -0.0167 & & 0.0708 & 0.0000 & 0.0731 & ++ & --- \\
\hline & Laminaria hyperborea & & -0.0084 & -0.0352 & & 0.0115 & -0.0001 & 0.0001 & 0.0001 & 0.0149 & +++ & --- \\
\hline & Laminaria ochroleuca & & -0.0317 & & & & & & & & & \\
\hline & Saccharina latissima & & 0.0094 & -0.0318 & & -0.0001 & -0.1250 & -0.0309 & -0.0079 & 0.0000 & --- & --- \\
\hline & Saccorhiza polyschides & & -0.0324 & 0.0035 & & 0.0243 & & & -0.0070 & 0.1434 & & \\
\hline \multirow[t]{7}{*}{ Wracks } & Ascophyllum nodosum & & 0.0000 & & & 0.0071 & & 0.2500 & -0.0298 & 0.0091 & & +++ \\
\hline & Fucus serratus & & 0.0074 & -0.0313 & & -0.0034 & & -0.0075 & 0.0000 & -0.0379 & & \\
\hline & Fucus spiralis & & -0.0130 & & & 0.0323 & & -0.0125 & -0.0333 & 0.0000 & & -- \\
\hline & Fucus vesiculosus & & 0.0072 & 0.0395 & & 0.0001 & & 0.1428 & -0.0227 & 0.0113 & +++ & +++ \\
\hline & Himanthalia elongata & & -0.0094 & & & 0.0154 & & & -0.0150 & 0.0776 & & $\begin{array}{lll}- & -\end{array}$ \\
\hline & Pelvetia canaliculata & & 0.0000 & & & 0.0000 & & & -0.0278 & -0.0481 & +++ & \\
\hline & Sargassum muticum & & -0.0439 & 0.0314 & & 0.3138 & & & & & +++ & +++ \\
\hline SST Change & Summer & & 0.023 & 0.032 & & 0.031 & 0.019 & 0.039 & 0.018 & 0.026 & & \\
\hline$\left({ }^{\circ} \mathrm{C} \text { per year }\right)^{\star}$ & Winter & & 0.019 & 0.022 & & 0.016 & 0.016 & 0.031 & 0.016 & 0.021 & & \\
\hline
\end{tabular}


Fig. 1a. Change in abundance by geographic region for kelp species. Points indicate records of abundance at a site covering 2 or more different years of observations. Inset line graphs show abundance $(y=1-4)$ over time $(x=1974-2010)$ for individual sites, so each coloured line shows a site-specific trend in abundance. Black lines show median slope of all the site specific trends, dashed grey lines show 95\% confidence intervals for the median slope lines. For example, L. hyperborea in the English channel has many sites showing declines (red lines), resulting in a strong overall negative trend (black line).

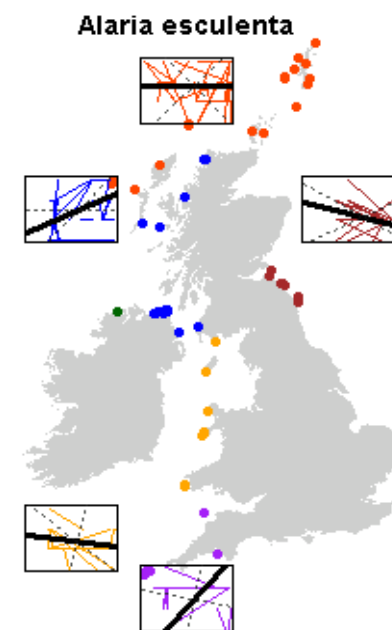

Laminaria ochroleuca

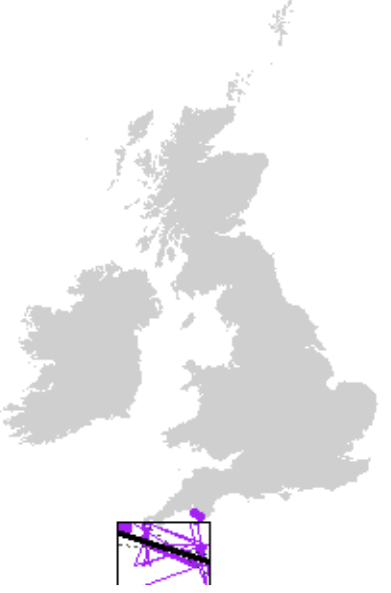

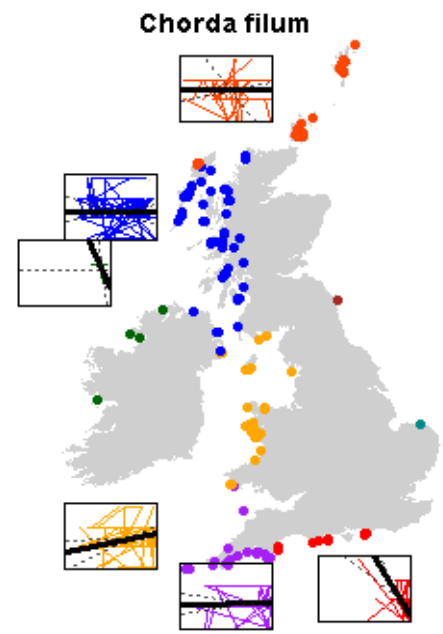

Saccharina latissima

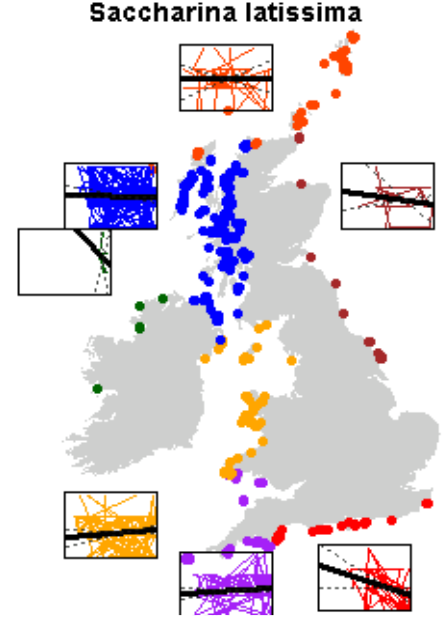

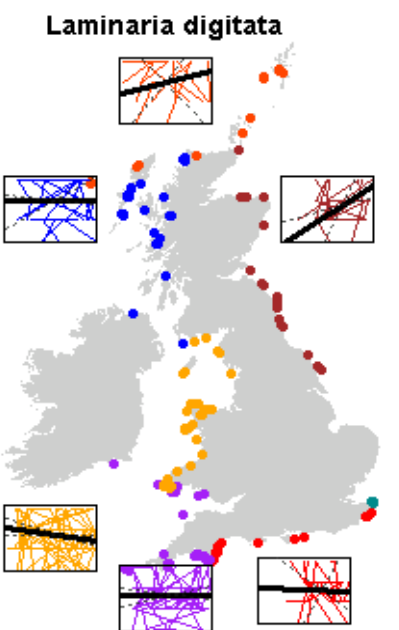

Saccorhiza polyschides

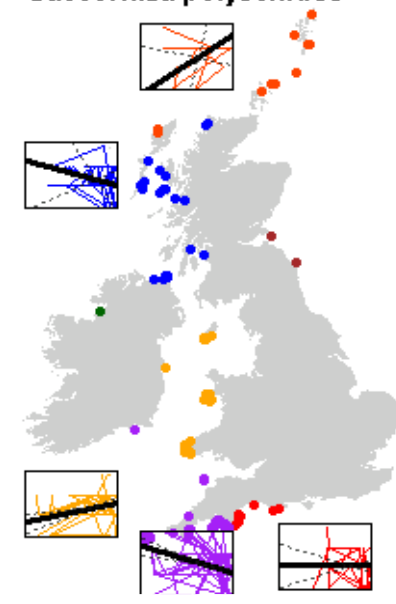

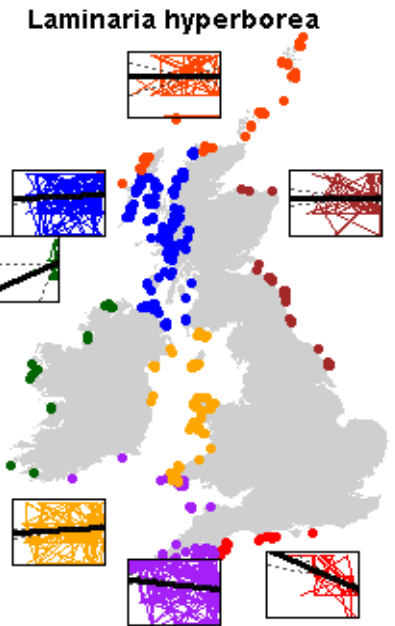

Change in Abundance by Biogeographic region

$$
\begin{aligned}
& \text { - West Ireland } \\
& \text { - North Sea (N) } \\
& \text { - English Channel (E) } \\
& \text { - W. Channel \& Celtic Seas } \\
& \text { - SW Atlanti } \\
& \text { - Western Scotlan } \\
& \text { Scottish Shelf } \\
& \text { Median slope of change } \\
& \text { Median slope } \mathrm{Cl}
\end{aligned}
$$


Fig. 1b. Change in abundance of Wrack species 1974-2010. Format as Figure 1a.
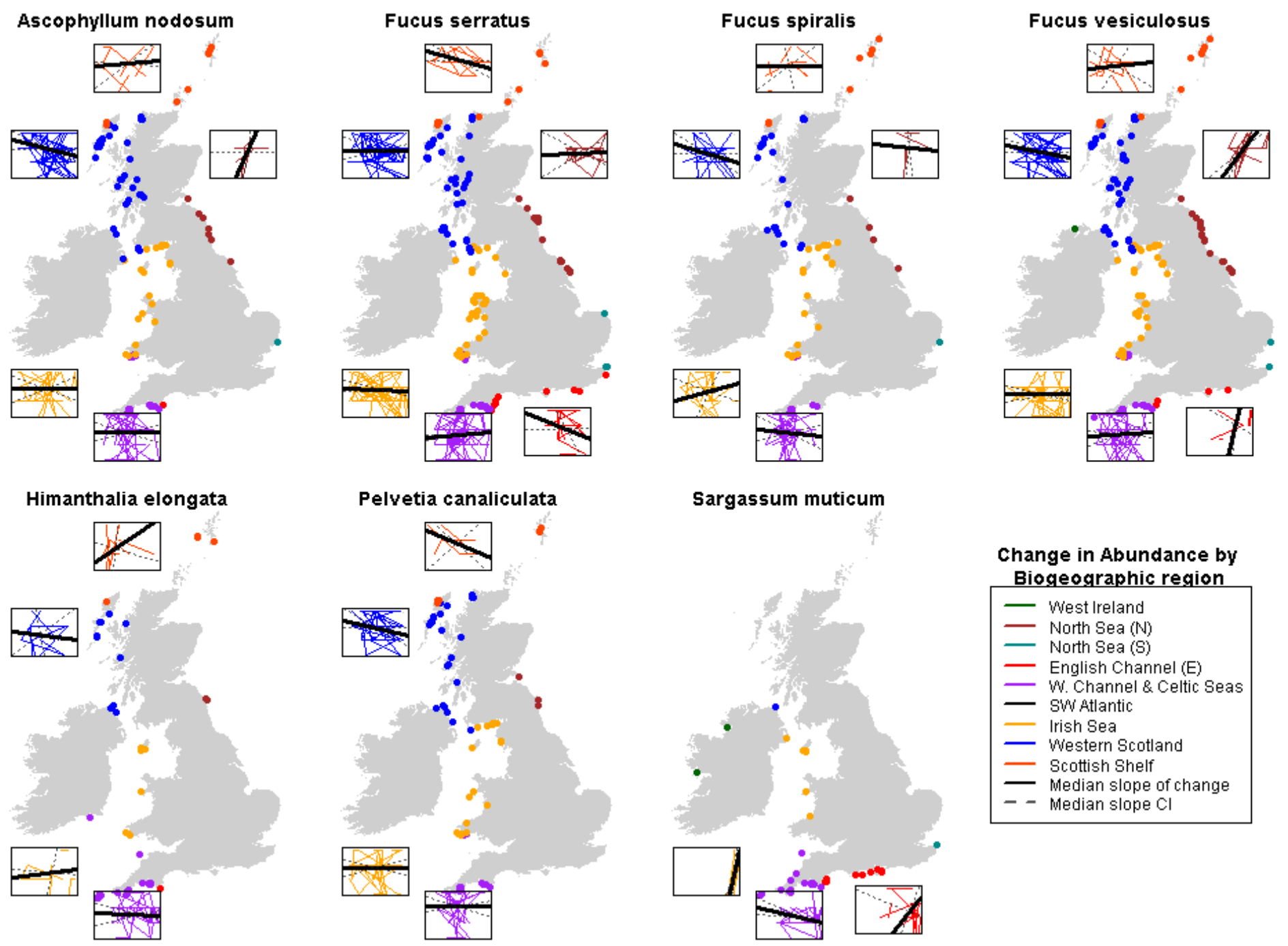

\section{Sargassum muticum}

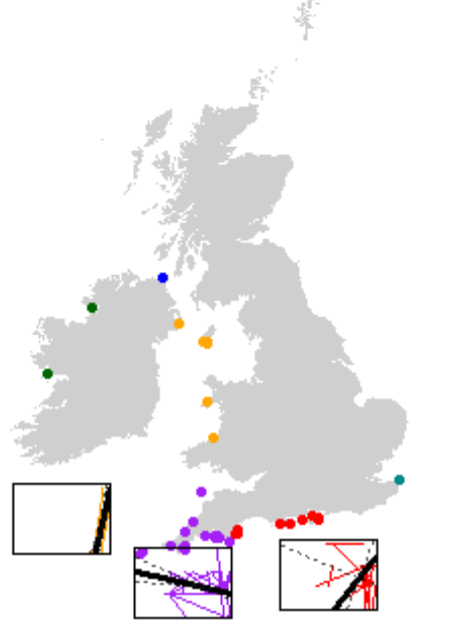

Change in Abundance by Biogeographic region

$$
\begin{aligned}
& \text { - West Ireland } \\
& \text { - North Sea (N) } \\
& \text { - English Channel (E) } \\
& \text { W. Channel \& Celtic Seas } \\
& \text { - SW Atlantic } \\
& \text { — Western Scotland } \\
& \text { - Scottish Shelf } \\
& \begin{array}{l}
\text { - Median slope of change } \\
\text { - Median slope } \mathrm{Cl}
\end{array}
\end{aligned}
$$


Fig. 2. Sea surface temperatures 1974-2010 based on locations with seaweed abundance data. Coloured lines are annual means, black lines show trend. Points show locations with seaweed abundance data. Inset line charts show mean sea surface temperature (SST) for each region.

\section{Sea Surface Temperatures 1974-2010 at seaweed sites (mean Summer SSTs top line, Winter bottom)}

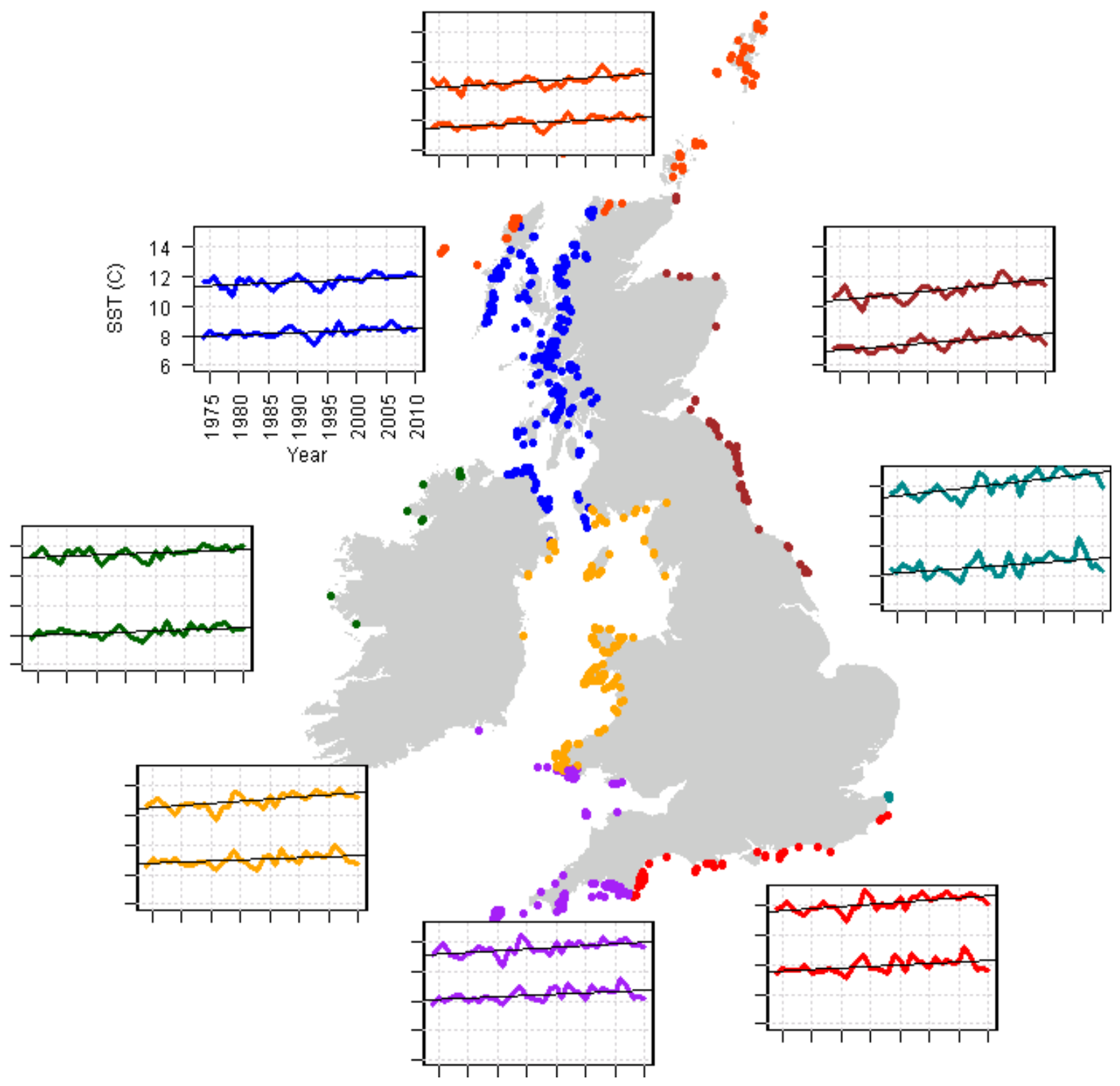


Change in abundance of large brown seaweeds

Supplementary Table S1. Details of generalised linear mixed models testing importance of sea surface temperatures in explaining abundance patterns. Highlighted cells show $\mathrm{p}<0.05$.

\begin{tabular}{|c|c|c|c|c|c|c|c|c|c|c|c|c|c|c|c|}
\hline $\begin{array}{l}\text { Model } \\
\text { details }\end{array}$ & Species & $\begin{array}{r}\text { Alaria } \\
\text { esculenta }\end{array}$ & $\begin{array}{r}\text { Ascophyllum } \\
\text { nodosum }\end{array}$ & $\begin{array}{c}\text { Chorda } \\
\text { filum }\end{array}$ & $\begin{array}{r}\text { Fucus } \\
\text { serratus }\end{array}$ & $\begin{array}{r}\text { Fucus } \\
\text { spiralis }\end{array}$ & $\begin{array}{r}\text { Fucus } \\
\text { vesiculosus }\end{array}$ & $\begin{array}{r}\text { Himanthalia } \\
\text { elongata }\end{array}$ & $\begin{array}{r}\text { Laminaria } \\
\text { digitata }\end{array}$ & $\begin{array}{r}\text { Laminaria } \\
\text { hyperborea }\end{array}$ & $\begin{array}{r}\text { Laminaria } \\
\text { ochroleuca }\end{array}$ & $\begin{array}{r}\text { Pelvetia } \\
\text { canaliculata } \\
\end{array}$ & $\begin{array}{r}\text { Saccharina } \\
\text { latissima } \\
\end{array}$ & $\begin{array}{c}\text { Saccorhiza } \\
\text { polyschides }\end{array}$ & $\begin{array}{r}\text { Sargassum } \\
\text { muticum }\end{array}$ \\
\hline & $\mathbf{N}$ & 747 & 1,007 & 1,216 & 1,603 & 1,044 & 1,546 & 604 & 1,515 & 3,239 & 143 & 1,019 & 2,919 & 1,066 & 262 \\
\hline \multicolumn{16}{|c|}{ Fixed variables } \\
\hline \multirow[t]{2}{*}{ Time } & Std Dev & 0.0 & 1.4212 & 34.5544 & 0.2409 & 0.2206 & 5.6757 & 1.3212 & 4.3213 & 10.5274 & 3.0822 & 3.0918 & 7.9733 & 0.0003 & 3.7741 \\
\hline & Residual & 0.6 & 34.9917 & 18.8777 & 0.5109 & 0.4865 & 6.7712 & 13.6231 & 12.4616 & 7.0125 & 8.4701 & 18.7702 & 9.5694 & 3.2227 & 11.0755 \\
\hline \multicolumn{16}{|c|}{ Explanatory variables } \\
\hline \multirow[t]{4}{*}{ Intercept } & Estimate & 2.1 & -0.9 & -6.4 & 3.1 & 3.6 & 0.5 & 3.4 & 2.4 & 6.5 & -0.4 & 2.8 & 2.7 & 10.5 & 1.1 \\
\hline & Variance & 0.331 & 0.788 & 7.056 & 0.191 & 0.261 & 1.254 & 1.159 & 1.160 & 2.109 & 4.098 & 0.974 & 2.107 & 0.527 & 1.940 \\
\hline & $\mathbf{z}$ & 6.244 & -1.155 & -0.903 & 16.058 & 13.749 & 0.429 & 2.937 & 2.030 & 3.071 & -0.088 & 2.888 & 1.266 & 19.871 & 0.582 \\
\hline & $p$ & 0.000 & 0.248 & 0.367 & 0.000 & 0.000 & 0.668 & 0.003 & 0.043 & 0.002 & 0.930 & 0.004 & 0.206 & 0.000 & 0.561 \\
\hline \multirow{4}{*}{$\begin{array}{l}\text { Summer } \\
\text { SST (linear) }\end{array}$} & Estimate & -0.003 & -0.017 & -0.010 & -0.016 & -0.027 & 0.083 & -0.041 & 0.052 & 0.097 & 0.282 & -0.133 & -0.021 & -0.192 & 0.269 \\
\hline & Variance & 0.030 & 0.031 & 0.022 & 0.014 & 0.016 & 0.010 & 0.066 & 0.020 & 0.021 & 0.230 & 0.020 & 0.015 & 0.046 & 0.069 \\
\hline & $\mathbf{z}$ & -0.099 & -0.559 & -0.428 & -1.173 & -1.632 & 8.403 & -0.629 & 2.647 & 4.565 & 1.228 & -6.529 & -1.446 & -4.163 & 3.902 \\
\hline & $\mathbf{p}$ & 0.921 & 0.576 & 0.669 & 0.241 & 0.103 & 0.000 & 0.529 & 0.008 & 0.000 & 0.222 & 0.000 & 0.148 & 0.000 & 0.000 \\
\hline \multirow{4}{*}{$\begin{array}{l}\text { Winter SST } \\
\text { (linear) }\end{array}$} & Estimate & 0.041 & 0.403 & 0.500 & -0.018 & -0.077 & 0.164 & -0.128 & -0.223 & -0.241 & -0.237 & -0.027 & -0.009 & -0.583 & 0.555 \\
\hline & Variance & 0.036 & 0.058 & 0.047 & 0.018 & 0.024 & 0.014 & 0.059 & 0.030 & 0.036 & 0.212 & 0.028 & 0.045 & 0.067 & 0.096 \\
\hline & $z$ & 1.145 & 6.999 & 10.712 & -1.008 & -3.190 & 11.680 & -2.184 & -7.482 & -6.640 & -1.122 & -0.960 & -0.199 & -8.707 & 5.784 \\
\hline & p & 0.253 & 0.000 & 0.000 & 0.314 & 0.002 & 0.000 & 0.029 & 0.000 & 0.000 & 0.264 & 0.337 & 0.842 & 0.000 & 0.000 \\
\hline \multicolumn{16}{|c|}{ Spatial autocorrelation } \\
\hline \multicolumn{2}{|l|}{ Range (m) } & 1 & 34,482 & 78,850 & 1 & 1 & 112,726 & 84,288 & 39,196 & 37,570 & 2,838 & 94,811 & 89,529 & 4,320 & 26,247 \\
\hline
\end{tabular}

